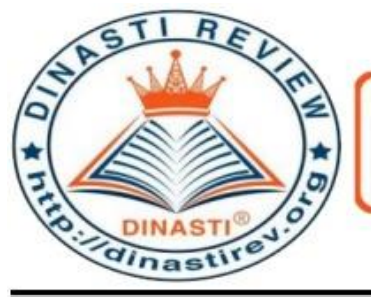

\title{
IMPLEMENTASI ETIKA BISNIS DAN GOOD CORPORATE GOVERNANCE PADA PT BRANTAS ABIPRAYA (PERSERO)
}

\section{Syaiful Arif}

Universitas Mercu Buana, Jakarta, Indonesia

\section{ARTICLE INFORMATION}

Received : 8 April 2020

Revised : 25 April 2020

Issude : 9 Mei 2020

Corresponding author : Syaiful Arif

E-mail :

Ipoel.bren@gmail.com

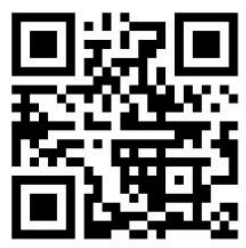

DOI:10.31933/JEMSI
Abstrak: Kegiatan bisnis Jasa konstruksi tumbuh dengan dengan pesat dan meluas menjadi bidang usaha yang mempunyai peranan penting dalam keberhasilan pembangunan nasional salah satu sebagai bentuk mendukung program pemerintah, dengan cara pemerataan pembangunan serta pencapai citra Indonesia sebagai negara maju. Jassa konstruksi Tidak hanya menyumbangkan dampak positif, tetapi juga ada dampak negatif berupa eksternalitas yang semakin meningkat. Pelaku bisnis perlu diingatkan untuk memberikan fokus pada antisipasi dampak negatif, tidak semata-mata mengarah pada keuntungan. Brantas Abipraya (persero) salah satu perusahaan Badan Usaha Milik Negara di Indonesia, pengelolaannya telah menjalankan bidang usaha secara etika dan tata kelola perusahaan yang baik. Bentuk pelaksanaanya adalah menerbitkan standar pedoman etika dan tata kelola perusahaan yang baik. Dalam kurun waktu setiap tahunnya perusahaan melakukan evaluasi dan penilai baik secara internal maupun eksternal. Implementasi etika dan tata kelola perusahaan dapat dirasakan peningkatan kinerja perusahan yaitu keuntungan, pertumbuhan dan nama baik.

Kata Kunci : Etika Bisnis, Tata Kelola Perusahaan, Konstruksi, BUMN

\section{PENDAHULUAN}

Bidang usaha penyedia jassa konstruksi tumbuh meningkat dan menyebar menjadi usaha yang mempunyai fungsi penting dalam keberhasilan pembangunan nasional. Beragam sarana infrastruktur umum maupun sosial di pelbagai daerah seluruh telah dibangun, guna mengisi kebutuhan masyarakat akan sarana dan prasarana dalam konteks ingin membeberkan perekonomian nasional dan pemerataan daerah.

Kenyataan di tengah semarak pembangunan bidang usaha jassa konstruksi, yang seharusnya mengutamakan kualitas, keamanan dan kenyamanan, masih ada komunikasi diluar konteks antara birokrasi pemilik (owner) dengan kontraktor (stakeholder) yang mengakibatkan hasil konstruksi yang tak sesuai dengan persyaratan teknis sehingga tidak memenuhi standar dan tidak berkualitas. 
Petunjuk umum yang muncul adalah adanya masalah keinginan dari berbagai faksi. Disatu sisi, penyedia jassa konstruksi dalam implementasi kegiatan konstruksinya berusaha untuk memperoleh keuntungan yang sebesar-besarnya, disisi lain pemilik modal juga berusaha untuk mendapatkan kualitas dan mutu yang lebih baik dari apa yang telah mereka bayar. Selain itu, minimnya pelaksanaan etika bisnis dan tata kelola perusahaan yaitu transparansi dalam prosses biaya tender dan rapuhnya kualitas dokumen tender.

Brantas Abipraya (persero) yakni salah satu Badan Usaha Milik Negara yang bergulir di bidang pemasok jassa konstruksi yang semasa ini berperan aktif di dalam pembangunan dalam mendukung kemajuan dan perkembangan di bermacam bidang. Sesuai dengan uraian diatas Brantas Abipraya mengecamkan arti pentingnya implementasi tata kelola perusahaan sebagai salah satu alat untuk meningkatkan nilai kemajuan usaha, meninggikan daya saing dan pertambahan bisnis jangka panjang secara menerus berkelanjutan kepercayaan pemangku kepentingan perusahaan (stakeholder). Sebagai anutan pemangku kepentingan seperti pegawai, mitra usaha, pemasok, pelanggan, masyarakat dan pemangku kepentingan lainnya merupakan faktor yang sangat menentukan bagi perkembangan dan kelangsungan usaha perusahaan.

Penyelenggaraan perusahaan selain harus mengikuti peraturan dan perundangan yang berlaku juga harus mengangkat norma dan nilai etika. Pemahaman untuk implementasi etika perusahaan harus memiliki asas yang berisikan norma dan etika yang dituangkan dalam pedoman perilaku perusahaan yang disebut Code of Conduct.

\section{KAJIAN PUSTAKA}

\section{Etika Bisnis (Business Ethic)}

Komitmen perusahaan pada lingkungan sosial merupakan suatu hal yang menarik untuk dikaji, Terpenting etika bisnis dan komitmen pada lingkungan social. Etika bisnis diartikan sebagai pengetahuan tentang cara ideal pengaturan dan pengelolaan bisnis yang memperhatikan norma dan normalitas yang berlaku secara universal dan secara ekonomi/sosial, dan pengetrapan norma dan normalitas ini menjunjung maksud dan target kegiatan bisnis, (Muslich, 1998).

Tekad etika bisnis adalah menyerukan pemahaman adab para eksekutor bisnis untuk mengimplementasikan good business dan tidak melansungkan monkey business atau dirty business. Etika bisnis menganjurkan para eksekutor bisnis melahirkan citra baik dan tata laksana bisnis yang baik (etis) agar bisnis itu cocok untuk dihadiri oleh semua orang yang yakin adanya dimensi etis dalam dunia bisnis. Hal ini serempak menolak citra baik dunia bisnis menjadi aktivitas yang keruh, licik, dan penipuan. Kegiatan bisnis memiliki keterlibatan etika, dan oleh karenanya membawa serta komitmen etika bagi eksekutornya.

Menurut Handayani, 2019. Dalam jurnal pedoman perilaku dalam etika bisnis, merupakan acuan mutlak dalam kegiatan berusahaan. Aktivitas usaha mampu memahami dan mengintreprestasikan yang dimaksud etika. Hal ini dapat meningkatkan kepercayaan diri dari rekan kerja.

\section{Etika Bisnis Dalam Kehidupan}

Melaksanakan bisnis dengan etiket artinya mengimplementasikan sistem cara berwirausaha yang bermoral dan ramah dalam kehidupan sehingga aktivitas bisnis menjadi nyaman karena saling menghormati. Norma berbisnis diaplikasikan pada sikap aktivitas berkantor, aksi menghadapi rekan-rekan bisnis, dan aktivitas dimana kita terhimpun dalam organisasi. Dalam bentuk 3 S, Senyum Salam Sapa. Etika bisnis melekat pada tata krama, hubungan sosial, hak dan tanggungan, hakikat dan norma.

\section{Penerapan Etika Bisnis Dalam Dunia Jasa Kosntruksi}

Wujud implementasi etika bisnis secara umum dalam perusahaan saat ini diterapkan dalam bentuk pedoman code of conducts atau kode etik di masing-masing perusahaan. Hal In, 
merupakan langkah awal dan pelaksanaan etika bisnis yakni memodifikasikan makna yang tersirat dalam etiket usaha bersama corporate culture, dalam bentuk komitmen yang tertuang dari perusahaan yang dilaksanakan dan tidak dilakukan oleh pengelola dalam melakukan kegiatan bisnis (Setyanto P. Santos8, 2007)

Menurut Arief. HM., Ali .H, 2019. Jurnal Business Ethic and Good Governance menyampaikan bahwa melaksanakan bisnis etik dengan komitmen yang dijalani setiap elemen. Komitmen yang dilakukan kepada sumber daya manusia, mitra dan pelangan.

\section{Good Corporate Governance (GCG)}

Tata kelola perusahaan yang baik adalah suatu mode dan susunan yang digunakan oleh bagian perusahaan untuk menambah kesuksesan wirausaha dan komitmen perusahaan untuk melahirkan nilai kepemilikan saham dalam waktu cukup panjang dengan tetap mengamati kepentingan stakeholders lainnya, berlandaskan tatanan dan norma etika. Perangkat perusahaan adalah RUPS, Komisaris, Direksi, Pemilik Modal. Selagi stakeholders adalah pihak yang menguasai ketertarikan dengan BUMN, baik serentak maupun tidak serentak yaitu pemegang saham, komisaris, pengurus perusahaan dan karyawan, pemerintahan, jassa permodalan, dan bagian lainnya.

Dua pendapat yang mendasar terkait taat kelola perusahaan adalah stewardship theory dan agency theory, (Chinn, 2000; Shaw, 2003.). Stewardship theory dalam bentuk asumsi makna menyinggung kepribadian manusia yakni manusia yang semestinya dapat dipercaya, bertanggung jawab, moralitas kejujuran terhadap bagian lain. Hal ini tertuang ikatan fidusia yang diharapkan pemilik saham. Stewardship theory menilai pengelola sebagian dapat dipercaya untuk melaksanakan sebaikmungkin untuk kepentingan umum maupun stakeholder.

Agency theory dipublikasikan oleh Michael Johnson, menilai bahwa pengelolah perusahaan sebagai "agents" bagi para pemilik saham, berperan dengan kesadaran untuk keperluan sendiri, tidak sebagai bagian yang cerdik dan bijaksana serta adil terhadap pemilik saham. Dalam progres selanjutnya, agency theory mendapat timbalbalik lebih luas karena dinilai lebih menerapkan realita yang ada. Gagasan mengenai tata kelola yang maju dengan bertumpu pada agency theory di mana penyelenggaraannya dilakukan dengan penuh komitmen kepada berbagai norma dan ketentuan yang berlaku.

Tata kelola yang baik secara pasti merupakan pola yang memerintahkan dan mengoperasikan perusahaan yang menghasilkan harkat bertambah (value added) bagi semua stakeholder (Monks, 2003). Ada dua hal penekanan dalam presepsi ini, pertama sangat penting pemilik saham untuk mendapatkan informasi dengan jelas dan tepat pada saatnya dan, kedua komitmen perusahaan untuk mengimplementasikan penyampaian (disclosure) secara waktu, keterbukaan terhadap semua penjelasan prestasi perusahaan, penyertaan, dan stakeholder.

Sesuai Forum for Corporate Governance in Indonesia (FCGI) mengartika Corporate Governance adalah serangkaian hukum yang mengikat antara pemilik, pengelola perusahaan, pendukung, pemerintah, pelaksana serta para pemilik ketertarikan pihak dalam dan pihak luar lainnya yang berhubungan dengan hak dan komitmen, disebut juga suatu pola pengendalian perusahaan. Corporate Governance bertujuan untuk menghasilkan manfaat bagi semua pihak yang berhubungan (stakeholders).

World Bank mengartikan GCG adalah sekumpulan hukum, norma dan pedoman yang wajib dipatuhi untuk mendorong kemampuan perusahaan bekerja dengan cara efisien, menumbuhkan nilai perekonomian jangka panjang berkesinambungan bagi para pemilik saham maupun masyarakat sekitar secara utuh. Konsep ini relatif maju sejak tahun 1990an, Sementara mode good corporate governance dikenalkan di Inggris pada Tahun 1992. Negara yang maju tergabung dalam organisasi OECD (Negara berkembang di Eropa Barat dan Amerika Utara) melaksanakan pada Tahun 1999. 
Menurut Kusmiarti, 2020. Dengan menjalankan Business Ethic dan GCG ada peningkatan kinerja perusahaan dan telah di buktikan perolehan penghargaan, selain itu hal tersebut diatas didukung dengan etika bisnis dengan 3 pilar yaitu Moralitas, Kapabilitas dan Integritas.

Prinsip-Prinsip GCG, menurut Keputusan Menteri BUMN Pasal 3 Nomor PER01/MBU/2011, mengenai Penerapan Tata Kelola Perusahaan yang baik Good Corporate Governance (GCG) pada perusahaan BUMN.

1. Transparansi (transparency), yaitu transparansi dalam implementasi pola pengambilan kebijakan dan keterbukaan dalam menyampaiakan informasi material dan relevan mengenai perusahaan;

2. Akuntabilitas (accountability), yaitu ketegasan fungsi, penerapan dan komitmen Organ sehingga pengelolaan perusahaan tercapai secara efektif;

3. Pertanggungjawaban (responsibility), yaitu kemiripan dalam aktivitas perusahaan terhadap peraturan dan prinsip corporate yang sehat;

4. Kemandirian (independency), yaitu kondisi corporate dikelola secara kompeten tanpa ada permasalahan keinginan sendiri dan pengaruh dari pihak manapun yang tidak sesuai dengan peraturan dan prinsip perusahaan yang sehat;

5. Kewajaran (fairness), yaitu keadilan dan kesetaraan di dalam mengabulkan hak pembuat Kepentingan (stakeholders) yang timbul berdasarkan perjanjian dan peraturan.

Tujuan Penerapan Prinsip-Prinsip GCG, menurut Keputusan Menteri BUMN Pasal 4 Nomor PER-01/MBU/2011, mengenai Penerapan Tata Kelola Perusahaan yang baik Good Corporate Governance (GCG) pada perusahaan BUMN

1. Mengoptimalkan nilai BUMN agar perusahaan memiliki daya sainga yang kompetetive, baik tingkat nasional maupun internasional, dengan tujuan untuk mempertahankan keberadaannya dan hidup berkelanjutan untuk mencapai maksud dan tujuan BUMN

2. Mendorong pengelolaan BUMN secara profesional, efisien, dan efektif, serta memmanfaatkan fungsi dan meningkatkan kemandirian Organ Persero/Organ Perum;

3. Mendorong agar organ persero/organ perum dalam membuat pedoman dan melaksanakan tindakan dilandasi nilai moral yang tinggi dan kepatuhan terhadap peraturan, serta pengetahuan akan adanya tangungjawab sosial BUMN terhadap pembuat kepentingan maupun kelestarian lingkungan di sekitar BUMN;

4. Meningkatkan keterlibatan BUMN dalam perekonomian nasional;

5. Meningkatkan suasana yang kondusif bagi perkembangan investasi nasional.

Dasar dari implementasi corporate governance adalah pengembangkan performance perusahaan melalui pengawasan performance pengelola dan adanya akuntabilitas pengelola terhadap penyelanggara kepentingan lainnya, berdasarkan kerangka aturan dan peraturan yang valid. Standarnya perusahaan yang mencapai target merupakan perusahaan yang memiliki nilai etika tinggi. Hal diatas mungkin terjadi karena penerapan harkat etika usaha yang tinggi, maka konsumen lainnya memberikan nilai puas sehingga bersedia mengikat peningkatan usaha dengan perusahaan tersebut, dengan demikian usaha perusahaan dapat terus dikembangkan. (Ali, 2018).

\section{Tahapan Implementasi GCG}

Impelementasi penerapan GCG dalam corporate adalah sangat utama bagi corporate dalam melaksanakan tahapan yang tepat berdasarkan analisis atas situasi corporate, dan keyakinannya, sehingga implementasi GCG dapat berjalan sesuai rencana dan menghasilkan support dari seluruh komponen di dalam corporate. Pada umumnya corporate yang sukses dalam implementasi GCG adalah menggunakan tahapan ini (Chinn, 2000; Shaw,2003). 
Tahap Persiapan: Tahap ini terdiri atas 3 langkah utama: 1) awareness building, 2) GCG assessment, dan 3) GCG manual building.

1. Awareness building adalah tahapan pendahuluan dapat membentuk pengetahuan mengenai makna penting GCG dan tanggungjawab bersama dalam mengimplementasikan. Tindakan ini dapat dilaksanakan dengan bantuan tenaga ahli independen dari luar perusahaan. Pelaksanaan kegiatan dilakukan melalui seminar, lokakarya, dandiskusi kelompok.

2. GCG Assessment merupakan kekuatan untuk memetakan situasi perusahaan dalam implementasi GCG saat ini. Langkah ini memastikan titik kondisi awal implementasi GCG dan untuk menandai langkah yang tepat guna mempersiapkan infrastruktur dan struktur perusahaan yang kondusif bagi implementasi GCG secara efektif. GCG assessment dibutuhkan untuk mengidentifikasi semua aspek yang perlu memperoleh perhatian terlebih dahulu, dan langkah apa yang dapat diambil untuk mencapai target yang lebih baik.

3. GCG manual building, sebagai tahapan setelah GCG assessment dilakukan. Menindaklanjuti hasil pemetaan kondisi kesiapan perusahaan dan bentuk identifikasi prioritas implementasi, penyusunan pedoman implementasi GCG dapat disusun. Penyusunan manual pedoman dapat dilaksanakan dengan oleh tenaga ahli independen dari eksternal perusahaan. Manual ini dapat dibedakan menjadi dua yaitu antara manual untuk organ perusahaan dan manual untuk keseluruhan anggota perusahaan, mencakup berbagai aspek seperti:

- Kebijakan GCG perusahaan

- Pedoman GCG bagi organ perusahaan

- Pedoman perilaku

- Audit commiteecharter

- Kebijakan penyampaian/disclosure dan transparansi

- Kebijakan dan kerangka manajemen resiko

- Roadmap implementasi

Tahap Implementasi : Setelah perusahaan memiliki GCG manual, langkah selanjutnya adalah memulai implementasi di perusahaan. Tahapan ini terdiri atas 3 langkah sebagai berikut:

1. Sosialisasi, dilaksanakan dengan maksud menghadirkan kepada seluruh perusahaan beragam segi yang terkait dengan implementasi GCG khususnya terkait pedoman implementasi GCG. Pelaksanaan sosialisasi perlu dilakukan dengan tim khusus yang dibentuk, langsung berada di bawah monitoring direktur utama atau direktur yang ditunjuk sebagai GCG champion di perusahaan.

2. Implementasi, yaitu kegiatan yang dilaksanakan sepaham dengan pedoman GCG yang ada, sesuai roadmap yang telah disusun. Implementasi harus bersifat top down approach yang melibatkan dewan komisaris dan direksi perusahaan. Implementasi hendaknya melingkupi upaya manajemen perubahan (change management) untuk memonitor proses perubahan yang ditimbulkan oleh implementasi GCG.

3. Internalisasi, yaitu tahap waktu yang panjang dalam implementasi. Internalisasi meliputi bentuk untuk mengenalkan GCG di dalam seluruh system usaha perusahaan kerja, dan berbagai peraturan perusahaan. Dengan sikap ini dapat dipastikan bahwa implementasi GCG bukan sekedar untuk kesigapan yang bersifat superficial, tetapi benar-benar contoh dalam seluruh aktivitas perusahaan.

\section{Tahap Evaluasi}

Kegiatan evaluasi adalah langkah yang harus dilaksanakan secara teratur berkala untuk menilai sejauh mana efektivitas implementasi GCG telah dilaksanakan dengan menunjuk independen selaku audit pelaksanaan dan penilain pelaksanaan GCG yang ada. Indonesia 
tersedia jassa yang melakukan scoring implementasi GCG. Evaluasi yang dilakukan adalah assessment dan scoring, kegiatan ini dilakukan secara ikatan kerja misalnya seperti yang dilaksanakan di lingkungan BUMN. Evaluasi ini diharapkan membantu perusahaan dalam pengambarkan kondisi dan situasi dalam pencapaian target perusahaan sehingga dapat dilakukan perbaikan yang berdasarkan rekomendasi yang disampaikan oleh tenaga ahli independen.

\section{METODE PENELITIAN}

Penelitian yang digunakan dalam artikel ini adalah metode deskriptif, yaitu menyajikan data analisa serta menginterpretasikan berdasarkan implementasi terhadap kebijakan perusahaan yang dapat menggambarkan pelaksanaan Business Ethics dan Good Corporate Governance di perusahaan. Sebagian besar metode pengumpulan data dan informasi yang digunakan dalam kajian ini didapatkan dari berbagai publikasi yang ditampilkan dalam alamat web perusahaan, pedoman perilaku tahun 2016, dan pedoman tata kelola perusahaan tahun 2016 dan laporan assessment implementasi GCG tahun 2017 pada Brantas Abipraya (Persero).

\section{HASIL DAN PEMBAHASAN}

Brantas Abipraya (Persero) mengetahui makna penting dari implementasi tata kelola perusahaan yang baik (GCG) yaitu salah pola peningkatkan image corporate, meningkatkan daya saing dan pertumbuhan usaha dalam kurun waktu jangka panjang secara berkesinambungan, untuk meningkatkan nilai pemilik saham (Shareholders) dan kepercayaan pelaksana kepentingan (Stakeholders). Kepercayaan pelaksana kepentingan seperti pegawai, konsorsium, supllier, konsumen, masyarakat dan pelaksana kepentingan lainnya merupakan faktor penting bagi pertumbuhan kelangsungan usaha perusahaan.

Kejujuran perusahaan dan kepercayaan erat hubungannya dengan etika perusahaan dalam bentuk interaksi dengan pelaksana kepentingan (Stakeholders). Aktivitas perusahaan yaitu mengikuti peraturan yang berlaku, dan menghargai perilaku etika kesadaran untuk melaksanaan guna meningkatkan dan memperkuat nilai positif perusahaan. Perusahaan wajib membuat standar pedoman tentang norma dan etika. Mulai tahun 2009 Brantas Abipraya (Persero) memiliki standar pedoman perilaku perusahaan, mengikuti kemajuan teknologi dan perubahan kebijakan, maka di melakukan penyesuaian pedoman perilaku perusahaan disebut Code of Conduct (CoC).

Penyampaian Code of Conduct (CoC) dibagi menjadi 3 bagian yaitu: Etika Bisnis Perusahaan, Etika Perilaku Karyawan serta Penegakan dan Pelaporan. Etika bisnis perusahaan yakni etika yang harus dipatuhi oleh perusahaan dalam menjalankan usahanya. Etika perilaku karyawan meliputi etika yang wajib ditaati oleh semua karyawan. Penegakan dan pelaporan meliputi pembuatan laporan dalam rangka evaluasi pelaksanaan perilaku usaha.

Landasan penyusunan pedoman perilaku (code of conduct), menurut Keputusan bersama dewan komisaris dan direksi PT Barntas Abipraya (Persero) Nomor 484.1/D/KPTS/XII/2016, tanggal 15 Desember 2016, mengenai penyempurnaan pedoman perilaku (code of conduct) PT Brantas Abipraya (Persero) antara lain:

1. Mengutamakan ketaati pada hukum, peraturan perundang-undangan, dan peraturan perusahaan serta menjunjung norma-norma yang berlaku pada masyarakat dimana Perusahaan beroperasi.

2. Menghindari tindakan, perbuatan yang dapat menimbulkan masalah kepentingan, korupsi, kolusi maupun nepotisme serta selalu menekankan kepentingan Perusahaan diatas kepentingan pribadi, keluarga, kelompok ataupun golongan.

3. Sadar bahwa Perusahaan dituntut untuk tumbuh dan berkembang sesuai dengan dinamika dan pertumbuhan market serta usulan pemilik saham dan tututan dari stakeholders. 
4. Mengutamakan keselamatan dan kesehatan bagi pegawai dan masyarakat dimana perusahaan beroperasi.

5. Kepedulian pada peningkatan kesejahteraan masyarakat, bangsa dan negara.

6. Menerapkan prinsip-prinsip Transparancy, Accountibility, Responsibility, Independency, Fairness (TARIF) dalam Mengelola Perusahaan

7. Mengakomodir nilai-nilai luhur yang dianut perusahaan

Tujuan Penerapan pedoman perilaku (code of conduct), menurut Keputusan bersama dewan komisaris dan direksi PT Barntas Abipraya (Persero) Nomor 484.1/D/KPTS/XII/2016, tanggal 15 Desember 2016, mengenai penyempurnaan pedoman perilaku (code of conduct) PT Brantas Abipraya (Persero) antara lain:

1. Sebagai komitmen bersama untuk mewujudkan visi dan melaksanakan misi Perusahaan secara profesional dan beretika bisnis.

2. Sebagai pedoman perilaku bagi seluruh karyawan yang harus dipatuhi dalam pelaksanaan semua aktivitas perusahaan.

3. Mendukung penuh seluruh karyawan berperilaku yang baik dalam menjalankan semua aktivitas Perusahaan.

4. Menciptakan suasana kerja yang sehat dan nyaman dalam lingkungan Perusahaan.

5. Sebagai acuan untuk menghindari masalah kepentingan dalam pelaksanaan semua aktivitas perusahaan.

6. Mewujudkan hubungan harmonis dengan pemegang saham dan Stakeholders

Manfaatn melaksanakan pedoman perilaku (code of conduct), menurut Keputusan bersama dewan komisaris dan direksi PT Barntas Abipraya (Persero) Nomor 484.1/D/KPTS/XII/2016, tanggal 15 Desember 2016, mengenai penyempurnaan pedoman perilaku (code of conduct) PT Brantas Abipraya (Persero) antara lain:

1. Meningkatnya nilai Perusahaan dengan memberikan kepastian dan perlindungan kepada Stakeholders dalam berhubungan dengan Perusahaan sehingga menghasilkan reputasi yang baik, mewujudkan keberhasilan usaha dalam waktu jangka panjang.

2. Terciptanya lingkungan kerja yang menjunjung tinggi nilai-nilai kejujuran, etika dan keterbukaan, sehingga akan meningkatkan kinerja dan produktivitas setiap karyawan menyeluruh

\section{Etika yang terkait dengan Stakeholders}

Kepercayaan adalah suatu unsur penting untuk menghasilkan loyalitas konsumen dan pihak lain yang bersama dengan Perusahaan. Selain kepercayaan, pelayanan menjadikan nilai tambah tersendiri bagi Perusahaan. Untuk menghasilkan keselarasan dan suasana usaha terpercaya, Untuk menjalankan usaha selalu dilakukan secara profesional, jujur, adil dan konsisten dalam menyampaikan pelayanan kepada Stakeholders antara lain :

1. Hubungan dengan Karyawan

2. Hubungan dengan Pelanggan/Konsumen.

3. Hubungan dengan Mitra Perusahaan

4. Hubungan dengan Kreditur

5. Hubungan dengan Masyarakat dan Lingkungan

6. Hubungan dengan Pemerintah (Regulator)

7. Hubungan dengan Pemegang Saham (Shareholder)

8. Hubungan dengan Pesaing

9. Hubungan dengan Media Massa

Selain etika bisnis perusahaan juga menerapan praktik Good Corporate Governance, telah menjadi kebutuhan hampir semua perusahaan-perusahaan di seluruh dunia. Badan Usaha Milik Negara di Indonesia terutama Brantas Abipraya (Persero) sebagaimana tertuang dalam Peraturan Menteri BUMN Nomor : PER-01/MBU/2011 tanggal 31 Agustus 2011 tentang 
Penerapan Tata Kelola Perusahaan Yang Baik (Good Corporate Governance) pada Badan Usaha Milik Negara sebagaimana telah diubah sesuai Peraturan BUMN Nomor : PER09/MBU/2012 tanggal 6 Juli 2012 tentang Perubahan Atas Peraturan Menteri BUMN Nomor : PER-01/MBU/2011 dan Keputusan Sekretaris Kementerian BUMN Nomor SK16/S.MBU/2012 tanggal 6 Juni 2012 Tentang Indikator/Parameter Penilaian dan Evaluasi Atas Penerapan Tata Kelola Perusahaan yang Baik (Good Corporate Governance) pada BUMN.

Memperhatikan pentingnya tujuan implementasi GCG, maka manajemen Brantas Abipraya (Persero) komitmen untuk menerapkan praktik GCG dalam aktivitas pengelolaan perusahaan. Komitmen tersebut diwujudkan dengan membuat sarana GCG yang melandasi penerapan GCG di lingkungan perusahaan, di antaranya adalah penyempurnaan Pedoman Corporate Governance (Code of Corporate Governance) yang menjadi pedoman bagi pengelola perusahaan (Pemilik Saham/RUPS, Komisaris dan Direksi) dalam melaksanakan praktik GCG di lingkungan perusahaan. Namun impelemtasi GCG pada perusahaan tetap harus dilaksanakan dengan tetap memperhatikan ketentuan yang ada, norma yang berlaku dan anggaran dasar. Disamping itu keberhasilan implementasi Pedoman Coporate Governance sangat tergantung pada komitmen dari seluruh pengelola perusahaan untuk memamtuhi dan melaksanakan tata kelola yang baik (GCG).

\section{Satuan Pengawas Internal}

Adalah kesatuan karyawan direktur untuk membantu memberikan keyakinan (assurance) dan pendapat yang bersifat independen dan obyektif dengan tujuan untuk meningkatkan dan memperbaiki operasional perusahaan yang sistematis dengan cara mengevaluasi dan meningkatkan efektivitas manajemen risiko, pengendalian dan proses tata kelola perusahaan.

\section{Auditor Eksternal}

Merupakan pihak yang independen dan profesional yang ditunjuk oleh RUPS dari calon yang diajukan oleh Komisaris untuk melakukan pemeriksaan laporan keuangan perseroan. Auditor eksternal merupakan auditor yang ditetapkan oleh RUPS dari calon yang diajukan oleh Komisaris berdasarkan usul Komite Audit, untuk memberikan pernyataan opini atas laporan keuangan yang disusun oleh manajemen.

\section{Assessment Penerapan Good Corporate Governance}

Assessment terhadap penerapan GCG pada PT Brantas Abipraya (Persero) dilakukan untuk memperoleh gambaran mengenai kondisi penerapan GCG dikaitkan dengan ketentuan yang berlaku dan praktik-praktik terbaik (best practices) penerapan GCG, sehingga area yang memerlukan perbaikan dan penyempurnaan dapat diidentifikasi. Hasil assessment akan menjadi masukan yang sangat penting bagi pengambilan keputusan di bidang penerapan GCG di masa yanga akan datang, sehingga manfaat diterapkan GCG tersebut dapat diperoleh secara optimal.

Berdasarkan assessment terhadap penerapan GCG PT Brantas Abipraya (Persero) untuk periode tahun 2017 yang dilakukan sejak tanggal 13 November 2017 sampai dengan tanggal 18 Desember 2017, dapat disimpulkan bahwa kondisi implementasi GCG PT Brantas Abipraya (Persero) mencapai skor 85,509 dari skor maksimal 100 atau mencapai 85,51\%, namun karena ada nilai pengurang dari aspek lainnya maka capaian tersebut berada dalam kategori "Baik".

Secara garis besar, capain skor terinci sebagai berikut:

Tabel 1. Resume assesment terhadap penerapan GCG

\begin{tabular}{|c|c|c|c|c|c|}
\hline \multirow{2}{*}{ No } & \multirow{2}{*}{ Aspek Governance } & \multirow{2}{*}{ Bobot } & \multicolumn{2}{|c|}{ Capaian } & \multirow{2}{*}{ Penjelasan } \\
\cline { 4 - 5 } & & & Skor & $(\%)$ & \\
\hline I & Komitmen terhadap penerapan tata & 7 & 8,214 & 88,77 & Sangat Baik \\
\hline
\end{tabular}




\begin{tabular}{|c|l|c|c|c|c|}
\hline & kelola secara berkelanjutan & & & & \\
\hline II & $\begin{array}{l}\text { Pemegang saham dan RUPS/Pemilik } \\
\text { modal }\end{array}$ & 9 & 8,189 & 90,99 & Sangat Baik \\
\hline III & Dewan Komisaris & 35 & 32,498 & 92,85 & Sangat Baik \\
\hline IV & Direksi & 35 & 32,742 & 93,55 & Sangat Baik \\
\hline V & $\begin{array}{l}\text { Pengungkapan informasi dan } \\
\text { transparansi }\end{array}$ & 9 & 7,866 & 87,40 & Sangat Baik \\
\hline VI & \multicolumn{1}{|c|}{ Aspek lainnya } & \pm 5 & $(2)$ & $(40)$ & - \\
\hline & Total & $\mathbf{1 0 0}$ & $\mathbf{8 5 , 5 0 9}$ & $\mathbf{8 5 , 5 1}$ & Baik \\
\hline
\end{tabular}

Sumber: Hasil Assessment BPKP Provinsi DKI Jakarta, 22 Desember 2017

\section{Tahapan Assessment}

\section{Reviu Dokumen}

Reviu dokumen dilakukan terhadap dokumen yang terkait dengan struktur dan proses governance perusahaan, antara lain: Anggaran Dasar, Code of Corporate Governance, Code of Conduct, Kebijakan Perusahaan, Kebijakan Manajemen, Risalah Rapat Umum Pemegang Saham, Risalah Rapat Komisaris dan Direksi termasuk Rapat Komite, Laporan Keuangan Tahunan, Dokumen Satuan Pengawasan Intern, dan dokumen lainnya.

\section{Kuesioner}

Pengisian kuesioner dilakukan untuk memperoleh gambaran persepsi responden atas implementasi peraturan/sistem/kebijakan/SOP sebagai bentuk penerapan GCG. Rancangan kuesioner disusun oleh Tim BPKP (asesor), sedangkan pemilihan responden dilakukan oleh pihak Brantas Abipraya (Persero) dengan kriteria yang diberikan oleh Tim BPKP.

Berdasarkan kelompok responden, jumlah kuesioner yang didistribusikan dan tingkat pengembaliannya sebagai berikut:

Tabel 2. Data koresponden kuesioner assessment terhadap penerapan GCG

\begin{tabular}{|l|c|c|c|}
\hline \multicolumn{1}{|c|}{ Responden } & Jumlah Kuesioner & Kembali & Response Rate \\
\hline Pemagang Saham & 1 & 1 & 100 \\
\hline Komisaris & 4 & 4 & 100 \\
\hline Komite Komisaris & 3 & 3 & 100 \\
\hline Direksi & 4 & 4 & 100 \\
\hline Manajer Kunci & 15 & 15 & 100 \\
\hline Karyawan & 190 & 190 & 100 \\
\hline Jumlah & $\mathbf{2 1 9}$ & $\mathbf{2 1 9}$ & $\mathbf{1 0 0}$ \\
\hline
\end{tabular}

Sumber: Laporan Assessment BPKP Provinsi DKI Jakarta, 22 Desember 2017

\section{Wawancara dan Observasi}

Wawancara dilakukan sebagai pendalaman lebih lanjut terhadap informasi yang tidak dapat diperoleh melalui reviu dokumen atau kuesioner. Rencana dan realisasi wawancara yang dilakukan untuk setiap kelompok responden adalah sebagai berikut:

Tabel 3. Data koresponden wawancara dan observasi assessment terhadap penerapan

$$
\text { GCG }
$$

\begin{tabular}{|l|c|c|c|}
\hline \multicolumn{1}{|c|}{ Responden } & Jumlah Kuesioner & Yang diwawancara & Response Rate \\
\hline Pemagang Saham & 1 & 1 & 100 \\
\hline Komisaris & 3 & 3 & 100 \\
\hline Komite Komisaris & 1 & 1 & 100 \\
\hline Direksi & 4 & 4 & 100 \\
\hline Manajer Kunci & 8 & 8 & 100 \\
\hline Jumlah & $\mathbf{1 7}$ & $\mathbf{1 7}$ & $\mathbf{1 0 0}$ \\
\hline
\end{tabular}


Sumber: Laporan Assessment BPKP Provinsi DKI Jakarta, 22 Desember 2017

Uraian hasil evaluasi penerapan GCG Brantas Abipraya (Persero) yang menunjukkan pemenuhan masing-masing indikator dan mencerminkan compliance dan atau mencapai best practices penerapan GCG sebagai berikut:

1. Aspek komitmen terhadap implementasi GCG secara berkelanjutan:

2. Aspek Pemegang Saham dan RUPS

3. Aspek Dewan Komisaris

4. Aspek Direksi

5. Aspek Pengungkapan Informasi dan Transparansi

6. Aspek Lainnya

a. Praktik Tata Kelola Perusahaan menjadi contoh atau benchmark bagi perusahaan perusahaan lainnya di Indonesia

b. Praktik Tata Kelola Perusahaan menyimpang dari prinsipprinsip Tata Kelola Perusahaan yang Baik sesuai Peraturan Menteri Negara BUMN No. PER01/MBU/2011, Pedoman Umum Good Corporate Governance Indonesia, dan standar-standar praktik dan ketentuan lainnya

\section{KESIMPULAN DAN SARAN}

Mulai tahun 2009 Brantas Abipraya (Persero) memiliki pedoman perilaku, namun seiring dengan adanya perkembangan teknologi dan perubahan peraturan, maka perusahaan melakukan penyesuaian terhadap pedoman perilaku disebut Code of Conduct (CoC). Penyajian Code of Conduct (CoC) dibagi menjadi 3 bagian yaitu: Etika Bisnis Perusahaan , Etika Perilaku Karyawan serta Penegakan dan Pelaporan.

Sejalan dengan penerapan etika bisnis, perusahaan juga menerapan praktik-praktik Good Corporate Governance sesuai Peraturan Menteri BUMN Nomor : PER-01/MBU/2011 tanggal 31 Agustus 2011 tentang Penerapan Tata Kelola Perusahaan Yang Baik (Good Corporate Governance) pada BUMN sebagaimana telah diubah sesuai Peraturan BUMN Nomor : PER09/MBU/2012 tanggal 6 Juli 2012 tentang Perubahan serta Keputusan Sekretaris Kementerian BUMN Nomor SK-16/S.MBU/2012 tanggal 6 Juni 2012 Tentang Indikator/Parameter Penilaian dan Evaluasi Atas Penerapan Tata Kelola Perusahaan yang Baik pada BUMN. Sehingga tahun 2017 telah dilakukan assessment implementasi GCG dapat disimpulkan bahwa kondisi implementasi GCG Brantas Abipraya (Persero) mencapai skor 85,509 dari skor maksimal 100 atau mencapai 85,51\%, namun karena ada nilai pengurang dari aspek lainnya maka capaian tersebut berada dalam kategori "Baik".

Dengan diterapkannya Business Ethic dan Good Corporate Governance adanya peningkatan kinerja perusahaan, dan ini telah dibuktikan oleh Perusahaan Brantas Abipraya (Persero), dengan diperolehnya berbagai penghargaan dari tahun ke tahun, Profitability, Growth dan citra. Tantangan kedepan adalah konsistensi untuk mempertahankannya terutama adalah Pertumbuhan Kinerja Perusahaan.

\section{DAFTAR PUSTAKA}

Ali, H. 2018. Modul Business Ethics \& Good Governance. Univeristas Mercu Buana. Jakarta. Andy Kirana, M.S.A. 1996. Etika Bisnis Konstruksi. Kanisius. Yogyakarta

Annissa, R. D. (2013, 04 06). Pentingnya Mengetahui Etika Bisnis Konstruksi. Retrieved October 22, 2014, from Understanding Architecture or be as a Architect: http://ratiharchratih.blogspot.com/2013/04/penting nya-mengetahui-etika-bisnis.html

Arief, HM., Ali, H. 2019. Business Ethic dan good corporate governance pada PT Sucaco Tbk. Universitas Mercu Buana, Jakarta. JIMTI E-ISSN 2686-4924.

DOI:10.31933/JMTI

Badan Pengawasan Keuangan dan Pembangunan Perwakilan Provinsi DKI Jakarta, 2017. Laporan Hasil Assessment Penerapan Good Corporate Governance pada PT 
Brantas Abipraya (Persero) tanggal 22 Desember 2017. Tersedia: http://www.brantas-abipraya.co.id/id/laporan-gcg/index. (30 maret $2020: 8.15$ WIB)

Chinn, Richard, Corporate Governance Handbook, Gee Publishing Ltd. London, 2000

Handayani, HNF., Ali, H. 2019. Pedoman Perilaku Dalam Etika Bisnis DI PT. KF. Universitas Mercu Buana, Jakarta.JEMSI E-ISSN 2686-5238.DOI:10.31933/JEMSI

Kurniawan, T. (2011, 01 05). Apa Itu Usaha Jasa Konstruksi, Retrieved October 22, 2014,

Monks, Robert A.G, dan Minow, N, Corporate Governance $3^{\text {rd }}$ Edition, Blackwell Publishing, 2003

Muslich. 1998. Etika Bisnis Pendekatan Substantif dan Fungsional. Yogyakarta: Penerbit Ekonisia

Shaw, John. C, Corporate Governance and Risk: A System Approach, John Wiley \& Sons, Inc, New Jersey, 2003.

Santosa, Setyanto P., 2007, Membangun dan Mengembangkan Etika Bisnis dalam Perusahaan, Kolom Pakar.htm (13 Agustus 2007)

Peraturan Menteri Negara BUMN, 2011. Penerapan tata kelola perusahaan yang baik (Good Corporate Governance) pada badan usaha milik negara tanggal 01 Agustus 2011. Tersedi : http://jdih.bumn.go.id/lihat/PER-01/MBU/2011. (30 maret $2020: 8.15$ WIB)

Peraturan Menteri Negara BUMN, 2012. Penerapan tata kelola perusahaan yang baik (Good Corporate Governance) pada badan usaha milik negara tanggal O6 Juli 2012. Tersedia: http://jdih.bumn.go.id/lihat/PER-09/MBU/2012. (30 maret 2020 : 8.15 WIB)

Keputusan Sekretaris Menteri Negara BUMN, 2012, Indikator/Parameter Penilaian dan Evaluasi atas Penerapan tata kelola perusahaan yang baik (Good Corporate Governance) pada badan usaha milik negara tanggal 06 Juni 2012. Tersedia: http://jdih.bumn.go.id/lihat/SK-16/S.MBU/2012. (30 maret $2020: 8.15$ WIB)

Keputusan Bersama dewan komisaris dan direksi PT Brantas Abipraya (Persero), 2016. Penyempurnaan pedoman perilaku (Code of Conduct) PT Brantas Abipraya (Persero) tanggal 15 Desember 2016. Tersedia: http://www.brantasabipraya.co.id/id/pedoman-gcg/index. (30 maret $2020: 8.16$ WIB)

Keputusan Bersama dewan komisaris dan direksi PT Brantas Abipraya (Persero), 2016. Penyempurnaan pedoman penerapan tata kelola perusahaan (Code of Corporate Governance) PT Brantas Abipraya (Persero) tanggal 15 Desember 2016. Tersedia: http://www.brantas-abipraya.co.id/id/pedoman-gcg/index. (30 maret $2020: 8.16$ WIB)

Kusmiarti, P., Ali, H. 2020. Iplementasi etika bisnis dan good corporate governance pada perkebunan kelapa sawit PT Bumitama Gunjaya Agro. Universitas Mercu Buana, Jakarta.JIMTI E-ISSN 2686-4924.DOI:10.31933/JMTI 